\title{
Relevant International Legal Obligations Due to the Environmental Impact of the Construction of W alls and Reinforced Fences
}

\author{
Enrique J. MARTÍNEZ PÉREZ
}

\begin{abstract}
4bstract: The aim of this paper is to analyse the main universal and regional environmental legal instruments applicable to the construction of defensive walls, as well as the international standards for the protection of living natural resources and certain shared resources, such as international watercourses. Additionalls, as such actions can give rise to violations of conventionalls protected environmental human rights, it will also examine the case law of the European and inter-American protection systems.
\end{abstract}

Kevwords: border wall, environmental impact assessment, international watercourses, biodiversity, environmental rights, national securit!

\section{(1) INTROD)(CTIO)}

The primary reason for building a border wall is to prevent the movement of people.' Only in exceptional cases are they built to prevent the movement of animals for public health reasons. ${ }^{2}$ Consequently, this increasingly common phenomenon is usually approached from the perspective of its dramatic impact on people. In contrast, not much attention has been given to the adverse environmental impact of such structures, even though all states acknowledge that they have (more or less significant) consequences when assessing them through the relevant procedures or internal administrative techniques.

This article will examine the relevance of international and European environmental law rules. In the author's view, of all the institutional, procedural and substantive rules in this area of international law, the obligation to undertake an environmental impact assessment is the basic requirement that every state must meet, due to its customary nature. Building on this basic rule, this paper will analy se the regional specificities of this technical-administrative instrument, making special reference to European Union law. Likewise, although not all scenarios involve them, it will look at the specifie legal system governing those elements classified as shared natural resources, including, amongst others, international watercourses and

ar Irlicle published on.31 December 2org

Tenured Lecturer of Public International Law and International Relations at the University of Valladolid. Mail: enriquejesus.martinez ${ }^{a}$ uva.es. This contribution was written during my stav as a visiting scholar at the I niversity of Cambridge

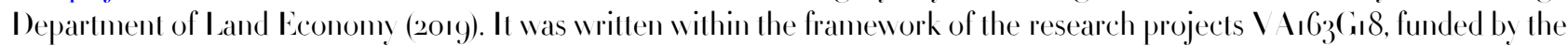
Regional Government of Castile and Leon.

II. Ruiz Fabri, 'Murs, accessibilité el libre circulation', in J.- M. Soreal (ed.), Les Wurs el le droil inlernalional (Pedone, Paris, 2010), at 153 .

2 A. Troumborst el al., 'Border Fences and Their Impacts on Lage Carnivores, Large Ilerbivores and Biodiversitv: An International Wildlife Law Perspective', 25 (3) Review of European Communily de Inlernational Environmenlal Law (2016) 291-306, al 292 |doi: hllps: doi.org 10.1111 reel.ı2ı6g). 
certain species of fauna and flora. This article will not address issues related to biological diversity, which are discussed elsewhere in this section.

The emvironmental damage arising from the installation of fences can also lead to human rights violations. Although some regional human rights protection instruments do recognize the right to the environment, they do so in only a very limited way. Jevertheless, their control bodies have endowed certain fundamental rights with an environmental dimension. The most important of these with regard to the topic at hand are those rights of a collective nature, especially from the perspective of procedural guarantees.

\section{(B) ENIRONME\TILIMPICT ISSESSMENTS}

All states must ensure that activities carried out in their territory do not cause damage to the environment of other states or areas beyond their national jurisdiction (sic ulere luo ul alienum non laedas principle). ${ }^{3}$ This is the obligation of prevention that requires states to take all appropriate measures to prevent significant transboundary harm or, in any case, to minimize the risk thereof.' As the International Court of Justice has indicated, a state would not be exercising its duty of vigilance and prevention were it to fail to carry out an emironmental impact assessment of a project's potential effects. ${ }^{5}$ However, the specific content of that obligation depends on the source thereof, with each state's domestic law determining the exact specifications.

\section{(1) The EI A: A Customary Obligation}

The lack of a regional conventional regime is no longer enough to circumvent this requirement because it is a customary obligation and has also been included in some of the main multilateral environmental agreements, including the Protocol on Environmental Protection to the Antarclic Treaty (Madrid Protocol), the United Xations Convention on the Law of the Sea (U VCLOS), the Convention on the Law of the Von-navigational U ses of International W atercourses, or the Convention on Biological Diversity.

In the Pulp Vills on the River Uruguay (Argentina v. Uruguay)ease, the International Court of Justice declared that it is an obligation, enshrined in general international law, to undertake an environmental impact assessment where there is a risk that an industrial activity might have a significant adverse impact in a transboundary context. ${ }^{7}$ Years later, in the San .Juan River (Vicaragua v. Cosla Rica) case, it went even further, stating that it should be applied to all proposed activities that may have a

\footnotetext{
3 Principle 2 of the Declaration of the United Vations Conference on the Human Environment (Stockholm, if June 1972) and Principle 2 of the Declaration on Environment and Development (Rio de Janeiro, I/ June 1992).

1 On this principle, see: S. Salinas, 'La Evaluación de Impacto Ambiental: Instrumento privilegiado de aplicación del principio de prevención en el Derecho internacional y de la U nión Europea', La Evaluación de Impaclo Imbienlal y su régimen jurídico (Lajouane, Buenos Aires, 2012) 271-31/1.

5 Pull Vills on the River ( ruguay (Argentina v. L ruguay), Judgment, IC.J Reports 2010, para. 20/.

P.- М. Iupuy and J. V iñuales, Inlernalional Environmenlal Law (Cambridge I niversity Press, Cambridge, 201 . ), al 7o.

7 Pull Wills on the River U ruguay ( Irgentina v. U ruguay), para. 20/.
} 
significant adverse impact in a transboundary context. ${ }^{8}$ The Seabed Disputes Chamber of the International Tribunal for the Law of the Sea went one step further in its Advisory opinion on Responsibilities and Obligalions of Slales sponsoring persons and entilies with respect to aclivilies in the trea, considering that the "Court's reasoning in a transboundary context may also apply to activities with an impact on the environment in an area bevond the limits of national jurisdiction; and the Court's references to "shared resources' may also apply to resources that are the common heritage of mankind".? More recently, the arbitral award in the South China Sea (Philippines v. China) case confirmed that this obligation is not limited to transboundary contexts, considering it "an essential part of a comprehensive environmental management system"."

If the assessment confirms that there is a risk of significant lamage, the state of origin of the activity must officially notify and consult with the affected state (and, where applicable, the competent international organizations or secretariats of the multilateral agreements) sufficiently in advance with a view to taking appropriate measures to prevent or mitigate the risk, offering enough information for the cooperation process to fully make sense. Whilst it has been recognized that states have a certain margin of discretion regarding their approach to the assessment, the obligation to report its results is absolute."

\section{(2) The Environmental Risk Threshold (Screening)}

The first stage of this process consists in determining whether the projected activity triggers this obligation, which requires the state to carry out a preliminary and systematic assessment on a case-by-case basis (a process known as "screening"). Some international legal instruments, such as the Convention on Environmental Impact Assessment in a Transboundary Context (Espoo, 25 February r991), ${ }^{22}$ facilitate this decision by listing the activities likely to cause an adverse transboundary impact. "3 Nlthough the Convention does not mention the kinds of infrastructure discussed here, that does not mean that they are automatically excluded, as its provisions could be applied if the parties involved so agree, provided that the proposed activities have an adverse transboundary impact due to their size, location (proximity to an international border) and effects over long distances.'

According to the Rio Declaration, "Environmental impact assessment, as a national instrument, shall be undertaken for proposed activities that are likely to have a significant adverse impact on the emironment and are subject to a decision of a compelent national authority." The responsible parties

\footnotetext{
8 Cerlain Activilies Carried Oul by Nicaragua in the Border of the Area (Cosla Rica v. Nicaragua) and Construction of a Road in Cosla Rica along the San .Juan River Nicaragua v Cosla Rica), Judgment, IC.J Reports 2or 5 , para. 10/4.

9 Responsibilities and Obligations of Slates with respect to Activities in the Area, Advisory Opinion, I February 2011, ITLOS Reports 2orı, para. 1/48.

1) South China Sea Arbitration (Philippinesv. China), Arbitral Tribunal constituted under Annex V II to the rg 82 U nited Vations Convention on Law of the Sea, Final Award, PC I Case Vo. 2013-19, 12 Juls 2or6, para. 9 48.

" Ibid., para $9 \mathbf{1}^{8}$.

12 Espoo Convention on Environmental Impact Assessment in a Transboundary Context (adopted 2ృ February r99ı).

13 Annex I.

1/. Article $2(5)$ in conjunction with Annex III.

5.5 Principle 17 (emphasis added).
} 
cannot circumvent this obligation simply by underestimating or ignoring the risk, for, as the International Law Commission observed in the Drafi arlicles on Prevention of Transboundary IIarm from IIazardous Iclivilies of 2001, the "notion of risk is thus to be taken objectively, as denoting an appreciation of possible harm resulting from an ac livity which a properly informed observer had or ought to have had". '. Therefore, the fact that certain activities are excluded under domestic law, subject to government approval, could be a violation of the due diligence required under the prevention principle. ${ }^{17}$

The International Court of Justice has ruled, on several occasions, that the risk of transboundary harm must be significanl. ${ }^{8}$ In the Drafi articles on Prevention, the International Law Commission uses the term significant, in the sense of "something more than 'detectable' but |that| need not be at the level of "serious" or "substantial". The harm may be caused in different spheres, such as human health, the environment or agriculture, and it must be possible to measure it by "factual and objective standards", providing rigorous evidence and proof. The project's size and impact on especially protected areas are very important factors for determining this risk. ${ }^{19}$ In any case, significant should be understood to involve "more factual considerations than legal determination”. ${ }^{20}$

\section{(3) Scope and Content (Scoping)}

Most of the international agreements currently in foree do not specify the scope and content of these environmental impact assessments. Therefore, in theory, each state must determine the specific content thereof in its domestic law." Itowever, as has been indicated in the literature, due diligence and the basic elements of this customary obligation must be respected. ${ }^{22}$ This obligation of due diligence cannot be uniformly applied, but rather requires considering the evolving context and standards, ${ }^{23}$ including new scientific and technological knowledge. ${ }^{21}$

According to the International Law Commission's recent Drafi guidelines on the prolection of the almosphere, it is necessary to speak of "the obligation to ensure that an environmental impact assessment is undertaken", because it is an obligation of conduct insofar as what the state is required to do is to put a legislative framework into place so that the assessment can be conducted, even though it may be economic

16 Drafi Articles on Prevention of Transboundary IIarm from IIazardous Aclivilies wilh commenlaries, Report of the International Law Commission on the work of its fifty-third session, Yearbook of the Inlernational Law Commission (20or-II), Part. 2, U \ Doc. A/5 6 10, commentary on Article s (para. 1/4).

17 J. E. V iñuales, 'La protección ambiental en el Derecho consuetudinario internacional', 69 Revisla Española de Derecho Inlernacional (2017), 7ı-9ı, at 8 j |doi: h11ps: doi.org 10.17103 redi.69.2.2017.1.03)|.

18 Pull Wills on the River U ruguay, para. 20;; Cerlain aclivilies Carried Oul by Vicaragua in Ihe Border Area, para. I53.

19) South China Sea Arbitration, para. 988.

20 Text of the drafi guidelines on the prolection of the almosphere, logether wilh preamble, adopled by the Commission on first reading, Report of the International Law Commission, Seventielh session (3o April z June and 2 July - ı August 2018 ), U I doc. $\mathrm{N}_{73}$ Io, commentary on Guideline (para. j).

${ }_{21}^{21}$ Pull Wills on the River I ruguay, para. 20/4

${ }_{22} \quad \mathrm{~V}$ iñuales, supra n. 17, at 87 .

${ }_{23}$ Text of the drafl guidelines on the prolection of the almosphere, commentary on Guideline 3(para. j).

${ }_{21}$ Responsibilities and Obligations of Slales wilh Respect to Aclivilies in the Area, para. 17. 
actors who carry it out. ${ }^{25}$ However, it must include at least an "evaluation of the possible transboundary harmful impact" of the activity on persons, property and the environment, so that the potentially harmed states can assess the risk to which they are exposed. ${ }^{26}$ Furthermore, it is not enough to adopt appropriate rules and measures; a certain level of vigilance in their enforcement and administrative control of public and private operators must be exercised as well. ${ }^{27}$

It is not easy to determine the specific content of this stage, a process known as "scoping", at the international level. The Conference of the Parties to the Convention on Biological Diversity explains this slage of the process thusly:

'During scoping relevant impacts are identified resulting in the terms of reference for the actual impact study. The scoping stage is considered critical in the process as it defines the issues to be studied and it provides the reference information on which the review of the study results will be based. Scoping and review usually are linked to some form of public information, consultation or participation. |... Scoping |is used| to identify which potential impacts are relevant to assess (based on legislative requirements, international conventions, expert knowledge and public involvement), to identify alternative solutions that avoid, mitigate or compensate adverse impacts on biodiversity (including the option of not proceeding with the development, finding alternative designs or sites which avoid the impacts, incorporating safeguards in the design of the project, or providing compensation for adverse impacts), and finally to derive terms of reference for the impact assessment. ${ }^{28}$

In clear keeping with this description, the Espoo Convention establishes minimum requirements for what the report must include: a description of the proposed activity and its purpose; a description, where appropriate, of reasonable alternatives (for example, locational or technological) to the proposed activity and also the no-action alternative; a description of the environment likely to be significantly affected by the proposed activity and its alternatives; a description of the potential environmental impact of the proposed activity and its alternatives and an estimation of its significance; a description of mitigation measures to keep the adverse environmental impact to a minimum; an explicit indication of predictive methods and underlying assumptions as well as the relevant environmental data used; an identification of gaps in knowledge and uncertainties encountered in compiling the required information; where appropriate, an outline for monitoring and management programmes and any plans for post-project analysis; and a nontechnical summary including a visual presentation as appropriate (maps, graphs, etc.). ${ }^{29}$

In any case, the environmental impact assessment does not end with the mere submission of a report; it is a continuous obligation, meaning the project's effects must be monitored, where necessary, throughout its lifespan. $3^{\circ}$

${ }_{25}^{25}$ Text of the drafi guidelines on the prolection of the almosphere, commentary on Guideline 4(para. 2).

26 Irafi Irlicles on Prevention of Transboundary IIarm from IIazardous Aclivilies, commentary on article 7 (para. 7).

${ }_{27}$ Responsibilities and Obligalions of Slates wilh Respect to Activities in the Area, para. 17.

28 Decision VIII/28. Impact assessment: Voluntary guidelines on biodiversity-inclusive impact assessment,

U IEP/CBD COP $8 / 3$ I, ı. June 2006, para. 2-5 (b).

29 Appendix II.

30 Pull Wills on the River I ruguav, para. 20„; Cerlain activities Carried Oul by Nicaragua in Ihe Border Area, para. I6ı. 
Defensive infrastructure projects can have an adverse environmental impact if they lead to the fragmentation of habitats and wildlife populations, resulting in a lack of connectivity in a territory. At the same time, the construction of such structures can cause significant alterations in the course and flow of international watercourses, and they can act as dams in case of flooding. Nthough they do not specifically address these types of projects and activities, many legal instruments (both regional and universal) can prevent and mitigate their impacts.

\section{(1) The Impact on Species of Fauna and Flora}

Vew artificial barriers can become an obstacle to wildlife, scuttling decades of international conservation efforts to save certain animals." One of the main protection instruments is the Bonn Convention on the Conservation of Migratory Species of Wild Animals. ${ }^{32}$ Although many of its provisions are pertinent to the matter at hand, they have varying degrees of regulatory power. Thus, Article III, paragraph p, although quite relevant to this study, is merely a request or recommendation, requiring only that range states of a migratory species endeavour to eliminate or minimize the adverse effects of obstacles that impede or prevent the migration of protected species. In contrast, immediately thereafter, the Convention uses imperative language to establish the obligation to prohibit the taking of animals belonging to such species out of their natural habitat. ${ }^{33}$ Although the purpose of these ypes of infrastructure is not the premeditated capture of these species, ${ }^{34}$ they can nevertheless pose a hindrance for them, which would be in contravention of the Convention. ${ }^{35}$

The proposed new walls can also affect certain habitats that fulfil fundamental environmental functions for plants and animals, such as wetlands (as in the case of the actions on the border between Greece and Turkey, near the Evros Delta). In these cases, under the Ramsar Convention, ${ }^{36}$ the parties must formulate their planning so as to promote their conservation, report any changes in the environmental conditions of the wetlands due to human interference, and consult with each other in the case of shared wellands. ${ }^{37}$

Attention should also be given to regional treaties, such as the Migratory Bird Convention, ${ }^{3}$ which aims to protect migratory birds "in their movements across the United States of America and the United

\footnotetext{
3י J. D. C. Linnell el al., 'Border Security Fencing and W ildlife: The End of the Transboundary Paradigm in Eurasia?', I/4 (6) PlOS Biologv (2016) I-13 |doi: hllps:/ doi.org 10.1371 journal.pbio.1002/183.

$3^{2}$ Convention on the Conservation of Migratory Species of W ild Animals (adopted 23 June r979).

3 Irt. III. j.

Art. I.i.

3. A. Troumborst el al., supra n. 2, at 3oo.

36 Convention on Wellands of International Importance Especially as W aterfowl I Iabitat (adopted 2 February 1971).

37 Arts. $3-j$.

38 Convention for the Protection of Migratory Birds and Game Mammals (adopted 7 February r936). As amended 7 March
} 1972. 
Mexican States, in which countries they live temporarily" ${ }^{39}$ Under the Convention, the Parties undertake, amongst other things, to establish legal provisions to prevent the capture of these species.

\section{(2) And on International Watercourses}

The obligation to provide notification of projects that may have a significant adverse effect on other watercourse states is one of the principles provided for under the Convention on the Law of Xonnavigational Uses of International Watercourses, ${ }^{\circ}$ which sets out the rights and basic obligations in relation to these hydrological systems. It is also included in regional agreements concluded between watercourse states prior and subsequently to it. In any case, as the International Court of Justice has repeatedly pointed out, the provisions of these types of treaties can be approached dynanically, which would allow for new environmental requirements to be considered, with regard to both the undertaking of new activities and the continuation of activities implemented in the past. ${ }^{1}$

The construction and reinforement of the border wall between the US and Mexico, along a border spanning 3,175 kilometres, including 2,053 kilometres delimited by the Rio Grande, is subject to significant constraints included in the agreements governing that watercourse. The first is the Treaty Relating to Utilization of Waters of the Colorado and Tijuana Rivers of 19 1 4 . ${ }^{2}$ This treaty establishes an order of preferences regarding use of the water: domestic and municipal uses; agriculture and stock raising; electric power; industrial uses; navigation; fishing and hunting; and any other beneficial uses which may be determined by the |International Boundary and Water| Commission (an international body responsible for settling any differences that may arise in the Treaty's application). ${ }^{33}$ Some authors argue that, although the Treaty does not explicilly mention conservation as one of its priority functions, it can be inferred from some of its uses (fishing and hunting) and, especially, from practice in relation to the Treaty, including repeated actions to create nature reserves and conservation areas, which is a fundamental objective. Thus, any barriers that might be built along the riverbanks could impede the movement of migratory species required for them to access the water.'- IIowever, they could also affect water quality, which, although not expressly cited, would be related to the priority uses (domestic and agricultural use). In fact, one of the main disputes between the wo countries arose when the salinity levels of the water delivered to Mexico were too high, prompting the International Boundary and Water Commission to intervene. It was agreed that both Parties would consult with each other prior to undertaking any work involving surface or

\footnotetext{
39 Art. I.

10 Art. I2.

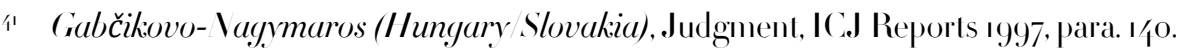

$1^{2}$ Utilization of Waters of the Colorado and Tijuana Rivers and of the Rio Grande Treaty, U.S.-Mexico (adopted 3 February r9/1), 3 U. \.T.S. 313 .

(13) Irt.3.

任 S. Mumme and O. Ibáñez, 'U.S.- Mevico Environmental Treats Impediments to Tactical Security Infrastructure Nlong the International Boundary', 49 Nalural Resources Journal (2009) 801-82\%, at 812.
} 
groundwater water resources that might adversely affect the other Party. It should moreover be recalled that these actions could violate Article i7, which provides that "Ithe use of the channels of the international rivers for the discharge of flood or other excess waters shall be free and not subject to limitation by either country.... (16 $^{6}$

The second is the Treaty to Resolve Pending Boundary Differences and Maintain the Rio Grande and Colorado River as the International Boundary, ${ }^{17}$ which is fundamental for settling disputes between the two countries along a very dynamic border located in a geographically complex region spanning numerous ecosystems. ${ }^{8}$ It aims to prevent alterations of the location of the dividing line due to the unilateral action of either state. Thus, in many cases, works in border areas must be carried out by mutual agreement. In this regard, Article IV allows each state to execute works on the course within its territory "provided, however, that in the judgment of the Commission the works that are to be executed under this paragraph do not adversely affect the other Contracting State through the deflection or obstruction of the normal flow of the river or of its flood flows". 99 If the Commission finds that the works executed in the watercourse or in its territory do have such consequences, "the Government of the Contracting State that constructed the works shall remove them or modify them and, by agreement of the Commission, shall repair or compensate for the damages sustained by the other Contracting State".$^{\circ 0}$ Therefore, as has been noted in the literature, should Mexico consider that US actions are in breach of the treaty, the United States could be required to take various remedial measures, from restitution (eliminating the security infrastructure) to compensation. ${ }^{51}$

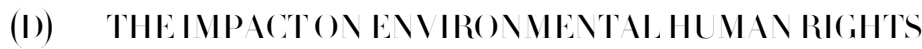

States' decisions to build border infrastructure can give rise to violations of environmental human rights protected by conventions, which, in turn, can lead to private actions before the jurisdictional bodies created by regional human rights protection systems. Of course, such actions are unlikely to succeed at the European level, because the legal goods susceptible to protection are considered on an individualized basis, meaning applicants must be directly and individually affected by the alleged violation. In contrast, in

\footnotetext{
1.5. Mnglés Hernández, 'Los cursos de agua compartidos entre México y los Estados L nidos de América y la variable medioambiental. Ina aproximación, 6 Anuario Mexicano de Derecho Inlernacional (2006) 89-166, at 113 |doi: hllp: d.doi.org 10.22201 iij.24,878-2e.2006.6.

$4^{6}$ K. Sulton and I. U luc; I Oonald Trump's Border W all and Trealy Infringement', I2 Mexican Law Review (2019) 3-31, at 26 |doi: hllp: d.doi.org 10.22201 iij.24/4 33060.2019 .2 .13636 .

it Treaty to Resolve Pending Boundary Differences and Maintain the Rio Grande and Colorado River as the International Boundary, U.S.-Mexico (adopled 23 November 1970), 23 U.S.T. 37.

is Sulton and Uluc, supra $\mathrm{n}$. 46 , at 17 .

19 Art.II.I.

$5^{\circ}$ Art. IV.B (2)

${ }^{5} \quad$ Sullon and Cluc, supra n. 46, al. 27.
} 
the Americas, such violations have been addressed from a community perspective, especially in relation to the interests of indigenous peoples.

\section{(1) The European Protection Sistem}

Veither the European Convention on Ituman Rights ${ }^{5^{2}}$ nor any of its protocols includes environmental rights. However, the European Court of Ituman Rights has developed original and extensive case law whereby certain attacks on the environment can give rise to violations of certain rights. Of all of them, Article 8 (right to respect for private and family life and non-violability of the home) has provided the most protection through the safeguard of various areas of personal autonomy. 53 However, this protection mechanism does not allow for complaints in abstraclo in defence of collective public interests, such as damage to natural resources, but rather requires personal injury. ${ }^{30}$ The individual must demonstrate that he or she has been directly affected by the alleged violation and that there is a sufficiently close connection. ${ }^{53}$ Additionally, env ironmental events must reach a "minimum threshold of severity" ${ }^{6}{ }^{6}$ meaning less serious behaviours are nol addressed.57

Complaints for environmental damage caused by infrastructure development are thus unlikely to succeed insofar as nothing other than the destruction of habitats and of fauna and flora species, as well as other shared resources, can be alleged. Some of the ECıIIR's decisions confirm this. In the Kyrlalos $v$. Greece case, which originated in a lawsuit brought by Greek citizens over the development of a marshland area adjacent to the applicants' home, the Court ruled that Article 8 of the Convention had not been violated because, although the marshland fauna was shown to have been damaged, this damage did not directly affect the applicants' private and family lives. ${ }^{-5}$ It moreover recalled that protection of the environment per se ${ }^{59}$ is not one of the Convention's objectives, and that other international instruments and domestic legistation are thus more pertinent in dealing with that aspect.

Another more recent case, ( thunbay and others $v$. Turkey) reflects the aforementioned challenges. The Court addressed the potential violation of various articles of the Convention (amongst others, Article 8 and Article 2 of Protocol Yo. I) due to the future loss of an archaeological site dating back more than 12,000 years (the city of Hasankey fin the Tigris Valley) as a result of the imminent construction of the Ilisu dam. ${ }^{60}$ The applicants' status as victims was based, first, on humanily's right to educalion, on the right to

$5^{2} \quad$ European Convention for the Protection of Iluman Rights and Fundamental Freedoms (adopted / Vovember i9.50).

53 E. Martínez, La Tulela Imbienlal en los Sislemas Regionales de Prolección de los Derechos IIumanos (Tirant lo Blanch, Valencia, 2017), at 6o.

3 Sdruženi.Jihočeské Walkvv. the Czech Republic (decision), no. I9101 o3, Io July 20o6, para. 2.I.

.3. Caron and Others v. France (decision), no. 48629 08, 29 June 2010, para. I.

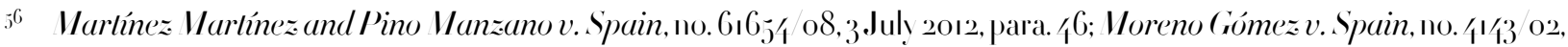
I6 November 200/, para. $j^{8}$.

${ }_{57}$ Fadeveva v. Russia, no. 5.723, oo, 9 June 2005, para. 68-69; Galev and Others v. Bulgaria (decision), no. 18324,0/, 29 September 2009; IIardy and Waile v. the I niled Kingdom, no. 31965 o7, \$ 188, 1/4 February 2012.

${ }_{5^{8}} \quad$ Kyrlalos v. Greece, no. $16666 / 9^{8,22}$ May 2003 , ECIIR 2003- I I, para. j3.

59) Para. $j^{2}$.

6o Ahunbar and olhers v. Turker (decision), no. 6080/06, 29 January 2019. 
know about one's cultural heritage and transmit that knowledge, which would lead to a violation of the right to information insofar as the planned works would prevent the transfer of values between civilizations. ${ }^{6 r}$ Second, they complained about the project's harmful effects on the environment, including the irreversible impact it would have on the region's ecology and landscape. ${ }^{62}$ After examining the applicable legal instruments in depth in order to determine whether there exists an emerging consensus or international trend in the matter, the Court concluded that there is indeed a shared European and international perception regarding the need to protect the right of access to cultural heritage. ${ }^{6}$ Ilowever, that shared perception only exists with regard to the right of certain minorities, ethnic peoples, to freely enjoy their own culture and to the right of indigenous peoples to maintain, control and protect their cultural heritage. ${ }^{6 /}$ In contrast, it found that it was impossible to infer from the Convention's provisions the existence of a "universal individual right to the protection of one or another part of the cultural heritage". The application was thus declared inadmissible ralione maleriae. ${ }^{6.5}$

\section{(2) The Inter-American Protection System}

Such a case might have resulted in a different judicial solution had it been brought in the sphere of the inter-American protection system, where ralione personae jurisdiction is less restrictive. Furthermore, the regulatory instruments establishing the catalogue of fundamental rights (the American Declaration of the Rights and Duties of Man ${ }^{66}$ of $194^{8}$ and the American Convention on Ituman Rights ${ }^{67}$ of 1969 ) afford protection to certain collective rights that considerably broaden the scope of environmental protection (mainly linked to indigenous peoples). This is of interest to the matter at hand, because, as noted in relation to the wall between the United States and Mexico, the wall's construction could jeopardize the access of such peoples to their ancestral lands and territories, their livelihoods, and the exercise of their cultural and religious practices. ${ }^{68}$ This is true even though the United States is not a party to the American Convention, or Pact of San José, as the Inter-American Commission can determine violations of the rights enshrined in the American Declaration of the Rights and Duties of Man, a source of international obligations, as the Court itself has repeatedly recognized. ${ }^{69}$

The Court's case law has repeatedly affirmed that indigenous communities are holders of cerlain

\footnotetext{
6. Para. 17.

6.2 Para. 18.

63 Para. 23.

6\% Para. 2/.

6. Para. 2j.

6i. American Declaration on the Rights and Duties of Man, adopted by the Ninth International Conference of American States (19/8) reprinted in Basic Documents Pertaining to Human Rights in the Inter-American System OE I Ser L V II.82 Doc 6 rev i al iz (1992).

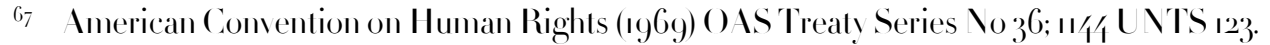

68 M. Guzman and Z. Iurwitz, I iolations on the Part of the Iniled Slales Government of Indigenous Righls IIeld by Vembers of the Lipan Ipache, Kickapoo, and I slela del Sur Tigua Tribes of the Texas-Vexico Border (The W orking Group) on Iluman Rights and the Border IV all, University of Texas, 2008).

69 I/ A Court II.R., Case of the Communily Garifuna Triunfo de la Cruz and ils members v. Ionduras. Merits, Reparations and Costs. Judgment of October 8, $20 y_{5}$. Series C No. 305 , para. 226 el seq.
} 
rights, as many of these rights can only be exercised through the community to which they belong:.$^{70}$ This is a recognition not only of the members of indigenous peoples, but of these peoples as such. Therefore, each individual member of such a people does not have to be personally present to defend his or her rights, as any violation has consequences for all of them and not for just some specifically. Under this case law, the Court has found violations of judicial guarantees and judicial protection, ${ }^{71}$ rights of movement and residence, ${ }^{7^{2}}$ and, most importantly for the case at hand, property.

Article 21 of the American Convention on Iluman Rights and Article XXIII of the American Declaration of the Rights and Duties of Man, which includes the right to private property, have been interpreted very broadly, ${ }^{73}$ bey ond the classic concept of property, ${ }^{71}$ considering that there is no single way of using and disposing of goods, but rather different ways depending on each community's cultures and customs. ${ }^{73}$ Hence, a communal form of collective ownership of the land, of a community's traditional territories, has been recognized, linked to the group rather than the individual, ${ }^{-6}$ which, at the same time, is respectful of the right to cultural identity and to the community's very survival.77 Amongst other things, these links can consist of "the traditional use or presence, be it through spiritual or ceremonial ties; settlements or sporadic cultivation; seasonal or nomadic gathering, hunting and fishing; the use of natural resources associated with their customs and any other element characterizing their culture" $7^{8}$

The territorial rights of indigenous peoples include the use and enjoyment of their natural resources. Although the Convention does not prohibit the development of infrastructure in their territories per se, such infrastructure may not jeopardize their traditional lifestyle or their cultural identity, social structure,

$7^{\circ}$ I/A Court II.R., Entillement of legal entities to hold rights under the Inler-Imerican IIuman Rights Syslem

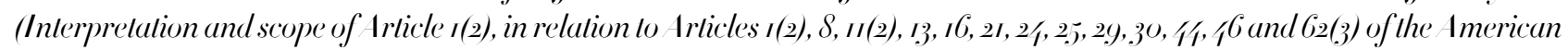
Convention on Iluman Rights, as well as of Article 8(I)(1) and (B) of the Prolocol of San Salvador). Ad isory Opinion OC2216 of February 26, 2016 . Series 1 No. 22, para. 83.

7 I A Court II.R., Case of the Communily Garifuna Triunfo de la Cruz and ils members v. ILonduras. Merits, Reparations and Costs. Judgment of October 8, 2015 . Series C No. 305 , para. 226 el seq.

$7^{2}$ I/A Court II.R., Case of the Ifro-descendant Communilies displaced from the Cacarica River Basin (Operalion Genesis) v. Colombia. Preliminary Objections, Merits, Reparations and Costs. Judgment of Vovember $20,2013$. Series C Vo. 270 , para. 315 el seq.

73 M. Barraondo, 'El caso Awas Tingni: la esperanza ambiental indígena', in F. Gómez Isa (ed), El caso de Awas Tingni contra Vicaragua: nuevos horizonles para los derechos humanos de los pueblos indigenas (Universidad de Deusto, Bilbao, 2003), at „22; S. Torrecuadrada, 'El cambio climático y los pueblos indígenas’, in A. Remiro Brolóns and R. I. Fernández Egea (eds), El cambio climálico en el derecho inlernacional y comunilario (Fundación BB \, Bilbao, 2009), al 29я.

7 I/ I Court II.R., Case of the Tucuru Indigenous People and ils members v. Brazil. Preliminary Objections, Merits, Reparations and Costs. Judgment of February , 2017. Series C No. $34^{6}$, para. $u_{5}$.

75 I A Court II.R., Case of Ihe Garifuna Punla Piedra Communily and ils members v. Ilonduras. Preliminary Objections, Merits, Reparations and Costs. Judgment of October 8, 2015. Series C Vo. 30, para. soo; Maya Indigenous Community of Ihe Toledo Districl v. Belize (Merits), Case 12.053, I ACIIR Report Xo. 40/0/1 (12 October 2004), para. II/.

$7^{76}$ I A Court II.R., Case of the Kalina and Lokono Peoples v. Suriname. Merits, Reparations and Costs. Judgment of November 25,2015 . Series C No. 309 , para. 129 .

77 I/ A Court II.R., Case of the Iakve Axa Indigenous Communilyv. Paraguav. Merits, Reparations and Costs. Judgment of June 17,2005 . Series C No. 12, p para. 1 彳 7 .

$7^{8}$ I A Court II.R., Case of the Sawhoyamaxa Indigenous Community v. Paraguay. Merits, Reparations and Costs. Judgment of March 29, 2006. Series C Vo. 1/46, para. I3. 
economic system, customs, beliefs and distinctive traditions. ${ }^{79}$ To ensure that restrictions respect this right to property, they must comply with three guarantees. The first is the need to ensure the effective participation of the indigenous peoples using procedures that are culturally adapted to their traditions. The second is the obligation to ensure that an environmental and social impact assessment is performed with the state's supervision. ${ }^{8}$ And the third and final one is to guarantee that the indigenous people will reasonably and equitably share in the projects' benefits. ${ }^{\delta_{2}}$

Also of interest to the present paper, it has been noted that the territory must be "sufficiently large and in one place, that is to say, it should not be fragmented, in order for those peoples to enjoy the full exercise of their ancestral ways of life". ${ }^{8}$ In fact, in a case now sub judice before the Inter-American Court, concerning precisely the division or parcelling up of territory, the Commission has already acknowledged that the petitioners are right in their consideration that Article 2 of the Convention had been violated when the state tolerated the installation of wire fences, as they did not meet some of the aforementioned requirements, that is, because prior, free and informed consultations had not been held, nor had social and environmental impact assessments been performed, nor had the indigenous communities' participation been ensured. ${ }^{8}$ It thus recommended the removal of the fences tended within the indigenous territory. ${ }^{85}$

\section{(E) FIN IL COXCLUSIO \S}

Infrastructure construction must respect the environmental legislation of each domestic legal system. However, when it is built to defend national security, that purpose can be used as grounds for not applying the obligations contained therein. An example of this is the actions of the US authorities, specifically, of the Department of IIomeland Security, which, under Section to2 of the Illegal Immigration Reform and Immigrant Responsibility Act of $199^{6}$, has waived an extensive range of environmental laws in order to build the border wall. ${ }^{86}$ European Union law also provides for the possibility of circumventing the application of some European environmental rules. For instance, the I Iabitats Directive ${ }^{87}$ provides for the possibility of carrying out a project despite a negative assessment of the implications for the site and in the

79 I/ A Court II.R., Case of the Saramaka People. v. Suriname. Preliminary Objections, Merits, Reparations, and Costs. Judgment of Jovember 28, 2007 Series C Vo. 172, para. I21.

8o I A Court II.R., Case of the Kaliña and Lokono Peoples v. Suriname, para. $202 \mathrm{el} \mathrm{seq.}$

8. I/ A Court II.R., Case of the Saramaka People.v. Suriname, para. 1 1.

$8 . \quad$ Ibid., para. $13^{8-1}$ 10. $^{\circ}$

8.3 Garifuna Communily of 'Triunfo de la Cruz' and Ils Members v IIonduras (Merits), Case 12.548, I ICIIR Report \o $76 / 12$ (7 Vovember 2012), para. 208.

8, Indigenous Communities of the Lhaka IIonhal (Our Land) 1ssocialion v. Argentina (Merits), Case 12.09я, I ICIIR Report \o. 2 12 (26.January 2012), para. 249.

8.5 Ibid., para. $2 j^{\circ}$.

86. Sulton and Uluc,supran. 46 , at 6 .

$8_{7}$ Council Directive $92 / 3$ EEC of 2 May 1992 on the conservation of natural habitats and of wild fauna and flora (O.J 1992 L 206). 
absence of alternative solutions for imperative reasons of public interest, such as public safety, ${ }^{88}$ provided that it can be shown that the interest overrides that embodied in the Directive's ecological objective. ${ }_{9}^{8}$

Such reasons cannot, however, be used to justify violations of internationally assumed environmental legal obligations. But as we have just seen, there are no conventional rules specifically addressing the environmental impact of this type of defensive infrastructure, or even concrete proposals to amend existing international agreements. Consequently, in the author's view, the permanent cooperation structures created by most of these conventions, in which the Conference of Parties plays a key part, must take on a decisive role insofar as they are tasked with taking the necessary decisions to promote and supervise the effective implementation of their provisions, periodically adapting the assumed commitments. ${ }^{90}$ Even if they are not binding for the parties, such decisions can embody a subsequent agreement or subsequent practice under Article 31.3 of the V ienna Convention on the Law of Treaties, ${ }^{91}$ i.e. "in so far as it expresses agreement in substance between the parties regarding the interpretation of a trealy". ${ }^{2}$

${ }_{88}$ Article 6(4) of the Ilabitats Directive. Ilowever, according to CJIU case law, "it must be recalled that, as an exception to the criterion for authorisation laid down in the second sentence of Article 6(3) of the Ilabitats Directive, Article 6(4) must be interpreted strictly" (Judgment of 21 July 2016, Orleans and Others, C-387 15 and C-388 15. EL:C:2016:583, para. 60).

89 Judgment of 28 February 1991, Commission 、Germany, C-57 89, EL:C:1991:89, para. 20 and 21 (in this case, however, it referred to Council Directive 79 409 EEC of 2 Ipril 1979 on the conservation of wild birds (OJ 1979 L L 103).

$9^{\circ}$ In this regard, see: R. Churchill and G. U llstein, 'Autonomous institutional arrangements in multilateral environmental agreements: A little-noticed phenomenon in international law', 94 American Journal of Inlernational Law (2000) 623-659

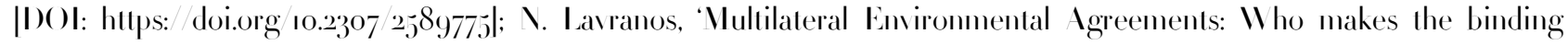

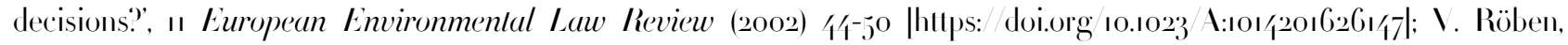
'Conference (Veeting) of States Parties', in R. Wolfrum (ed.), Max Planck. Encyclopedia of Public Inlernational Law, vol. II (Oxford University Press, Oxford, 2012) 605-6n; P. Sand, 'The role of environmental agreements: Conferences of the Parties', in Y. Kerbrat and S. Maljean-Dubois (eds), The Transformation of Inlernational Environmental Law (X. Pedone-I Iart, ParisOxford, 2011), $89-96$.

9r D. Bodansky, J. Brumnée and L. Rajamani, Inlernational Climale Change Law (Oxford Universily Press, Oxford, 2017), at 94; J. Brunnée, 'COPing with consent: law-making under multilateral environmental agreements, , ${ }_{5}$ Leiden Journal of Inlernational Law (2002) 1-52, al 3 1.

${ }_{92}$ Text of the drafi conclusions on subsequent agreements and subsequent practice in relation to the inlerprelation of treaties (Conclusion It, Decisions adopted within the framework of a Conference of States Parties), Report of the International

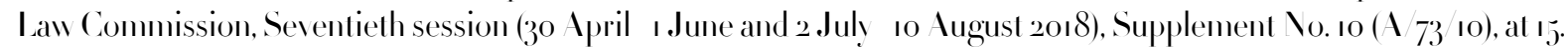

